\title{
Teachers' Efforts to Improve Pedagogic Competency in Learning Children with Special Needs in Inclusion Basic Schools
}

\author{
Aulia Nailul Muna ${ }^{1 *}$, Sunardi ${ }^{2}$, Herry Widyastono ${ }^{1}$ \\ ${ }^{1}$ Sebelas Maret University, Surakarta, Indonesia
}

\begin{abstract}
The purpose of this study was to determine the efforts of teachers to improve teacher pedagogical competence in the learning of children with special needs in the inclusive city of Surakarta. The subjects of this study were a class teacher and a subject teacher in ten inclusive schools in the city of Surakarta. This study uses a qualitative case study method, with data collection using interview techniques from aspects of pedagogic competencies and documents of children with special needs as individual teaching programs then technical data analysis using descriptive analysis. The results of this study that based on teaching experience and educational background, teachers still need to increase efforts to improve pedagogical competence in the learning of children with special needs in inclusive schools.
\end{abstract}

Keywords: Pedagogical Competence, Children with Special Needs, Inclusion Schools

\section{Research Background}

Inclusive schools are schools that can accept students with special needs, when regular schools use inclusive programs, the role of teachers is very important in developing inclusive programs in schools. Educators / teachers in the teaching and learning process have a key role in determining the quality of learning. Teachers are expected to show students how to get knowledge, attitudes, values and skills. (Yasin, 2011).

From this, teachers in inclusive schools need to get knowledge about students with special needs in order to understand students' special needs and their characteristics so that students with special needs in inclusive schools get educational services that suit their needs (Komariah, 2017).

National Education Standards (SNP) are education standards and educational personnel, which regulates the competence of teachers as educators. Teacher competence is defined as the unanimity of knowledge, skills and attitudes which are manifested in the form of intelligent and responsible actions owned by someone who claims to be a teacher as a profession. RI Law No. 14/2005 Article 10 paragraph 1 and PP RI No. 19/2005 Article 28 paragraph 3). 
Teacher competence is a set of abilities that must be possessed by teachers so that they can carry out teaching tasks. Based on the regulation of the Minister of National Education of the Republic of Indonesia number 16 of 2007 concerning academic qualification standards and teacher competence article 1 , every teacher is required to meet the academic qualification standards and teacher competencies that apply nationally. It is explicitly stated that there are four competencies that teachers must have as the main pillars of learning. The four competencies are pedagogical competence, personal competence, professional competence and social competence (Article 28 paragraph 3 of Government Regulation No.19 of 2005 concerning National Education Standards).

In the perspective of the national policy, the government has formulated four types of teacher competence, as stated in the explanation of Government Regulation No.19 of 2005 concerning National Education standards, one of which is pedagogical competence (Musfah, 2011). In this pedagogic competence, there are seven aspects that must be mastered by the teacher, including: recognizing the characteristics of students, mastering learning theory and teaching learning principles, curriculum development, educational learning activities, understanding and developing potential, communication with students and assessment. and evaluation (Arifin, 2017). Educators / teachers in the teaching and learning process have a key role in determining the quality of learning.

Teachers are expected to show students how to get knowledge of attitudes, values and skills. (Yasin, 2011). (Sunardi et al, 2004) there are functions and duties of teachers including: Educating, teaching, guiding and training, as an educator a teacher can develop the potential / basic abilities of students, develop student personalities, provide exemplary, create a conducive educational atmosphere. As a teacher, a teacher can plan learning, carry out educational learning, assess the results of the learning process.

As a guide, the teacher can, encourage the development of positive behavior in learning, guide students to solve problems in learning. As a trainer, a teacher can train the skills needed in learning, familiarize students with positive behavior in learning, Assist the development and management of school programs As program developers, teachers help develop school education programs and intra-school collaborative relationships As program managers, assist build school partnerships with other schools and communities. Developing professionalism As professionals, make efforts to improve professional abilities. Inclusive education teachers should have pedagogical competencies that can help development and learning for children with special needs starting from mastery of child characteristics, mastery of educational theories and principles of learning, and communication with students. It was explained by that the main duties of teachers which are regulated in the 2003 National Education System chapter XI concerning educators and education personnel, article 39 are: planning and 
implementing the learning process, assessing learning outcomes, conducting guidance and training. (Wahyudi, 2012).

Because of this, why in the teaching and learning process in the class pedagogical competence is the main competence of teachers in humanizing humans, in this case students elementary school, because the main task of the teacher as described in article 39 is contained in broad pedagogical competences. From the description above, the researcher wants to know how the teacher's efforts to improve pedagogical competence in the learning of children with special needs in inclusive schools discussion.

\section{Research Methodology}

This study uses a qualitative approach with descriptive methods, namely research that describes or describes systematically the teacher's pedagogical competence in learning children with special needs in inclusive schools in the city of Surakarta. Researchers used the interview method, the interview instrument refers to four aspects, namely: mastering the characteristics of children with special needs, with indicators: the teacher can identify the learning characteristics of each student; the teacher ensures that all students have the same opportunity to actively participate in learning activities; teachers can organize the classroom to provide equal learning opportunities to all students with physical disabilities and different learning abilities; the teacher tries to find out the causes of deviant behavior of students to prevent these behaviors from harming other students; teachers help develop potential and overcome the shortcomings of students; the teacher pays attention to students with certain physical weaknesses so that they can participate in learning activities, so that these students are not marginalized (marginalized, mocked, insecure, etc.) master learning theory and learning principles that educate children with special needs, with indicators: teacher provide opportunities for students to master learning material according to their age and learning ability through the arrangement of various learning processes and activities; the teacher always ensures the level of understanding of students with special needs towards certain learning materials and adjusts subsequent learning activities based on that level of understanding; the teacher can explain the reasons for the implementation of the activities / activities he does, both appropriate and different from the plan, related to the success of learning; teachers use various techniques to motivate the willingness to learn of students with special needs; planning learning activities that are interrelated with one another, taking into account the learning objectives and learning process of students; pay attention to the responses of students who do not / do not understand the learning material being taught and use it to improve the next learning design, develop learning designs according to the needs of children with special needs, with indicators that teachers can compile syllabi according to the curriculum and can compile curricula for children with special needs; The teacher can design a learning plan that is in accordance with the syllabus to discuss certain teaching materials so that students can achieve the established basic competencies; teachers can follow the 
sequence of learning materials by paying attention to the learning objectives of children with special needs; The teacher chooses learning materials that: (1) are in accordance with the learning objectives of students with special needs (2) are accurate and up to date, (3) are appropriate for the age and level of learning abilities of students with special needs, (4) can be implemented in class and (5) in accordance with the context of daily life of students with special needs.

Arranging educational learning for children with special needs, with indicators: the teacher carries out learning activities in accordance with a completely prepared design and the implementation of these activities indicates that the teacher understands the objectives; the teacher carries out learning activities that aim to help the learning process of students with special needs, not to test so as to make students with special needs feel depressed; the teacher communicates new information (for example additional material) according to the age and level of learning abilities of students with special needs; The teacher responds to the mistakes made by students with special needs as a stage of the learning process, not merely mistakes that must be corrected. For example: by knowing first the other students who agree / disagree with the answer, before giving an explanation of the correct answer; the teacher carries out learning activities according to the content of the curriculum and relates it to the context of the daily life of students; teachers carry out various learning activities with sufficient time for learning activities that are appropriate to the age and level of learning abilities and maintain the attention of students; teachers manage the classroom effectively without dominating or busy with their own activities so that all participants' time can be used productively; teachers are able to use audio-visual (including ICT) to increase students' motivation to achieve learning goals.

Adjusting learning activities designed with classroom conditions; teachers provide many opportunities for students to ask questions, practice and interact with other students; the teacher arranges the implementation of learning activities systematically to help the learning process of students. For example: the teacher adds new information after evaluating students' understanding of the previous material, and the teacher uses teaching aids, and / or audio-visual (including ticks) to increase student motivation to achieve learning goals.

The subjects of his research were a classroom teacher and a subject teacher in five inclusive schools in the city of Surakarta, namely: Mjs Public Elementary School, Bmt Public Elementary School, Mh Public Elementary School, Pjg Public Elementary School, and Crg State Elementary School. Data collection techniques through centralized interviews, this research was conducted in the inclusive elementary school in the city of Surakarta for about two months. Data analysis used data reduction, data presentation and drawing conclusions.

\section{Results}


The results of interviews with a classroom teacher and a subject teacher in five inclusive elementary schools in the city of Surakarta show that basically classroom teachers and subject teachers understand enough about the role of teachers in inclusive schools. However, the readiness of class teachers and subject teachers in dealing with children with special needs is still lacking. This is influenced by a shortage of special advisory teachers, as well as the difficulty of teachers in handling and providing learning for children with special needs, besides that the researchers found several things that indicate the inadequacy of classroom teachers and subject teachers in dealing with children with special needs, for example a lack of preparation in the formation of individualized programs. for children with special needs, lack of evaluation for children with special needs, lack of motivation for children with special needs.

The results of research on teacher pedagogical competence in learning children with special needs in inclusive schools, still show that pedagogical competences need to be developed and improved so that students with special needs in inclusion schools can get better guidance and teaching, as for the results of interviews conducted at Mjs Public Elementary Schools, which initially met with the principal and the principal told that in this place have not appointed a special companion teacher, and appointed one of the teachers from the local special school but for the arrival of special school teachers only once a week then the researcher met respondent 1 who was a class teacher, in recognizing the characteristics of students, the class teacher realized that they do not understand the character of children with special needs, and the teacher finds it difficult to teach lessons to children with special needs, and does not know what programs are suitable for the needs of children with special needs, from that, learning for children with special needs is equated with other normal children.

Respondent 2, who is a subject teacher, is also less familiar with children with special needs and usually equates learning programs with other normal children. Furthermore, at the Crg Public Elementary School the researcher conducted interviews with respondent 3 who were classroom teachers, the teacher also admitted that they did not understand, recognize and know what children with special needs need, and do not have special learning programs that are arranged for learning children with special needs. . These public elementary schools have special assistant teachers, but the qualifications of these teachers are not from special / special education. So the handling of children with special needs is not optimal because of the lack of knowledge to compile special learning programs for children with special needs. Then the researcher also conducted interviews with respondent 4 who was a subject teacher, the teacher also did not understand children with special needs, and did not compile special learning for children with special needs. So the learning model for children with special needs is still the same as other normal children.

Furthermore, at Bmt Public Elementary School, the researcher conducted interviews with respondent 5 who was a class teacher, the class teacher explained that it was difficult to face children with special needs, and left it completely to the special 
companion teacher. Respondent 6 , who is a subject teacher, told a little about the situation of children with special needs that were not handled properly due to the lack of readiness of teachers for learning children with special needs. And most teachers only leave it to a special companion teacher. Furthermore, at Mh Primary School, the researcher conducted interviews with respondent 7 who were class teachers, the teacher explained that they did not understand children with special needs, but the class teacher had attended inclusion school teacher training in the city of Semarang and was still struggling to pay special attention to children with special needs, little by little trying to compile a special learning program for children with special needs. Likewise with respondent 8 who is a subject teacher, the teacher tries to compile special programs for children with special needs.

Furthermore, at the Pj Elementary School the researcher conducted interviews with respondent 9 who were class teachers, the teacher had attended training for inclusive school teachers but the teacher found it difficult to apply it. In mastering learning theories and teaching learning principles, classroom teachers and subject teachers are not developing enough to implement various strategies, methods and techniques in learning for children with special needs, still on par with other regular students, curriculum development, in developing curriculum for children's learning Class teachers and subject teachers have not determined the appropriate material and objectives, and have not arranged the material learning in accordance with the chosen approach and adapting the characteristics of students for children with special needs.

Educational learning activities, classroom teachers and subject teachers have not prepared learning activities such as designing individual learning programs for children with special needs. Understanding and developing potential. In understanding and developing the potential of classroom teachers who have provided various learning activities to encourage students to achieve optimal achievement, providing various learning activities to actualize the potential of students, including creativity. Communication with students, classroom teachers and subject teachers have communicated with children with special needs. Evaluation assessment, assessment for children with special needs is different from other normal children, all children with special needs in inclusive schools get less than normal children.

\section{Discussion}

Currently, the number of children with special needs entering school age continues to increase, especially at the age of primary education. This clearly must be handled well, especially by teachers as the main pillar in the education unit which forms the initial foundation for children through their competencies. (Zafira and Gunansyah, 2015) . Teacher pedagogical competence which consists of managing student learning includes understanding of students, among the objectives expected from the study of competence to master the developmental characteristics and abilities of students in various ways, namely: the teacher understands the characteristics of students related to 
physical, intellectual, socio aspects. - emotional, moral, spiritual and socio-cultural backgrounds; the teacher identifies the potential of students in the subject to be forgiven; the teacher identifies the initial provisions of students in the subject being taught; and teachers identify physical and psychological difficulties of children in learning. (Arifin, 2017).

Based on the results of interviews conducted at the Mjs Public Elementary School, who initially met with the principal and the principal told that this place had not appointed a special companion teacher, and appointed one of the teachers from the local special school but for the arrival of special school teachers. only once a week then the researcher met respondent 1 who was a class teacher, in recognizing the characteristics of students, the class teacher realized that they did not understand the character of children with special needs, and the teacher found it difficult to teach lessons to children with special needs, and did not know what programs in accordance with the needs of children with special needs, from that, learning for children with special needs is equated with other normal children. This shows that in Inclusive Mjs Public Elementary Schools have not met the standards of inclusive schools, which according to Permendiknas No. 70 of 2009 Article 10 on inclusive education states that Special Advisory Teachers (GPK) who are in schools that provide inclusive education are at least 1 person. teacher. The same thing was also conveyed in the Regulation of the Mayor of Surakarta No. 9 of 2013 that the Regional Government and / or providers of inclusive education provide special tutors at regular schools for students with special needs who need them. Thus, inclusion schools are required to provide a minimum of 1 special supervisor (GPK). Then a subject teacher is also less familiar with children with special needs and usually equates the learning program is the same as other normal children. Furthermore, at Crg Public Elementary School, the researcher conducted interviews with respondent 3 who was a class teacher, the teacher also admitted that he did not understand, recognize and know what children with special needs need, and do not have special learning programs arranged for learning children with special needs.

These public elementary schools have special assistant teachers, but the qualifications of these teachers are not from special / special education. So the handling of children with special needs is not optimal because of the lack of knowledge to compile special learning programs for children with special needs. It can be indicated that what teachers actually need in this aspect is the understanding that in inclusive education teachers must be able to develop a curriculum model as described in the inclusive education training module (2010), there are four models of curriculum development for students with special needs who attend education in inclusive schools namely (1) the duplication model, namely imitating / duplicating, (2) the modification model, which is changing to be adjusted, (3) the substitution model, namely replacing, and (4) the omission model, which eliminates the purpose, content, process, and evaluation of curriculum which is then contained in the teacher's learning tools with adjustments to the characteristics and needs of students. Then the researcher also 
conducted interviews with respondent 4 who was a subject teacher, the teacher also did not understand children with special needs, and did not arrange special learning for children with special needs. So the learning model for children with special needs is still the same as other normal children.

Furthermore, at Bmt Public Elementary School, the researcher conducted interviews with respondent 5 who was a class teacher, the class teacher explained that it was difficult to face children with special needs, and left it completely to the special companion teacher. Respondent 6 , who is a subject teacher, told a little about the situation of children with special needs that were not handled properly due to the lack of readiness of teachers for learning children with special needs. Furthermore, at Mh Primary School, the researcher conducted interviews with respondent 7 who were class teachers, the teacher explained that they did not understand children with special needs, but the class teacher had attended inclusion school teacher training in the city of Semarang and was still struggling to pay special attention to children with special needs, little by little trying to compile a special learning program for children with special needs. Likewise with respondent 8 who is a subject teacher, the teacher tries to compile special programs for children with special needs. And most of the teachers submit learning to a special companion teacher. The amount of responsibility and intensity of teachers in teaching in inclusive schools fully guarantees the competence that they have, especially in the aspect of mastering the characteristics of students from physical, moral, social, cultural, emotional and intellectual aspects.

As for the aspect of understanding the potential characteristics of students with a variety of specificities for learning for children with special needs, including teachers mastering the characteristics of children with special needs; teachers recognize learning barriers for children with special needs from the aspects of cognitive functional barriers, language, social personal and self-help; able to identify the early abilities of children with special needs for learning needs.

Understanding the various characteristics of students, understanding the stages of development of students in various aspects and their application in optimizing the development and learning of students, with a variety of specialties, being able to identify the potential of students with a variety of specificities, mastering the potential characteristics of students with a variety of specialties; have a commitment to the rights and obligations of children with special needs, recognize and take advantage of the conditions of the community environment for the learning of children with special needs, behave and behave empathetically towards children with special needs.

The results of the teacher's understanding of the characteristics of these students will affect the quality of learning that is created, because in carrying out learning the teacher first identifies the initial provision of teaching with adjustments to the characteristics and needs of students. In accordance with the opinion (Sumantri and Syaodih, 2006) that the results of the learning process will be of higher quality, because 
the process of service and learning guidance carried out by teachers in schools will take place according to the development characteristics, interests and various talents of students.

This theory illustrates the importance of a teacher in understanding the characteristics of their students through the actions described by Lerner (1998) in the inclusive education training module (2010) that the purpose of identification is carried out for five purposes, namely (1) screening, namely identification activities that function marking and determining children who have physical, mental, intellectual, social and / or emotional disabilities, (2) referrals, namely identification activities carried out for the purpose of transferring to other professional personnel who are more competent in their fields if needed further observation, (3) classification, namely identification activities carried out for the purpose of determining or determining whether the child is classified as a child with special needs so that it requires special attention and handling in education, (4) instructional planning, is carried out for the purposes of preparation of peng program individual teaching, (5) monitoring of learning progress (monitoring pupil progress), is carried out to determine whether the specific learning program given is successful or not in improving children's abilities. If the teacher can apply this well, then clearly the teaching and learning activities will run optimally, because the design is based on the characteristics of students, both in terms of material, objectives, implementation and service. Teachers can easily carry out their duties, and students can receive their rights well.

Furthermore, in Pj Elementary School the researcher conducted interviews with respondent 9 who was a classroom teacher, the teacher had attended inclusive school teacher training but the teacher found it difficult to apply it. In mastering learning theories and teaching learning principles, classroom teachers and subject teachers are not developing enough to implement various strategies, methods and techniques in learning for children with special needs, still on par with other regular students, curriculum development, in developing curriculum for children's learning Class teachers and subject teachers have not determined the appropriate material and objectives, and have not arranged learning material according to the chosen approach and have adjusted the characteristics of students for children with special needs.

Mastery of the theory and principles of educational learning, the goal of mastering the theory and principles of educational learning includes teachers understanding various theories learning and educational learning principles related to the subjects being taught; teachers apply various approaches, strategies, methods and learning techniques that educate creatively in the subject matter taught, in mastering this aspect the teacher should know the ways and learning styles of children with special needs; teachers are able to identify ways and learning styles of children with special needs; teachers know and are able to do various ways to improve the abilities of children with special needs according to their learning styles; able to teach with an individual learning program model; able to teach one or more areas of special expertise in 
accordance with the various specificities of the child; able to complete learning programs according to the needs of every child with special needs; able to modify and adapt learning tasks according to the needs of children with special needs.

Developing a curriculum and its development strategy, some of the goals of developing a curriculum and developing a strategy for teachers to understand the principles of curriculum development; the teacher determines the learning objectives being taught; the teacher determines the appropriate learning experience to achieve the learning objectives being taught; the teacher chooses the instructed learning material that is related to the learning experience and learning objectives; the teacher delivers the learning material correctly in accordance with the chosen approach and the character of the students; and teachers develop competency achievement indicators. Then in the learning of children with special needs the teacher masters the basic principles of individual learning planning ; teachers can assess the learning of children with special needs; teachers can adapt curriculum materials to the learning needs of children with special needs; The teacher understands task analysis to develop teaching materials that are suitable for the characteristics of children with special needs, the teacher can design individual learning programs (PPI) for children with special needs.

Organizing learning activities, regarding this matter the teacher should understand the principles of educational design; the teacher develops the components of the learning design; the teacher compiles a complete learning design, whether for activities in the classroom, laboratory or field; teachers carry out educational learning in the classroom, in the laboratory and in the field using completeness standards; and teachers use learning media and learning resources that are relevant to the characteristics of students and subjects that are able to achieve learning goals as a whole, it is hoped that in learning in inclusive schools teachers are able to identify learning problems of children with special needs; the teacher is able to reflect on the learning process that has been done and the progress of student learning to improve the quality of learning; teachers are able to plan classroom action research to find solutions to learning problems for children with special needs; teachers carry out classroom action research to improve the quality of learning for children with special needs.

This is clearly not in line with the six principles of inclusive curriculum development outlined in the inclusive education training module (2010), one of which is that the general curriculum applied to regular students needs to be changed (modified) to suit the conditions of students with special needs.

The minimum competency standards that teachers must have in learning children with special needs, namely, understanding the characteristics and substance of knowledge, sources of teaching materials, understanding of the disciplines of special education in a broader context, the use of the methodology of the science concerned to verify and solidify the understanding of the concepts studied, and the adjustment of the substance of the science concerned with the demands and spaces of the curricular, as 
well as understanding of work procedures and ways of securing practical activities. As for mastering the substance of the field of study or special expertise ( such as: orientation and mobility, brave, speech and language development, self-development, movement development, personal and social development, creativity development), being able to relate and apply specific areas of expertise with applicable curriculum materials in schools according to the learning needs of children with special needs contextually and functionally, developing the concept of science or technology or art in the field of outside education ordinary, mastering the structure and curriculum materials that apply to educational institutions for children with special needs, being able to adapt special education scientific material to the development of students with special needs, planning and guiding the safety and health of students in the workplace or laboratory according to various specialties.

In solving the above case, formal training can be provided by the provincial office related to teacher competence in inclusive schools or peer tutors from teacher working group activities / subject teacher deliberations then non-formal training such as teacher learning forums and other teacher communities. And apply for a special companion teacher to the service / appoint a temporary teacher.

\section{Conclusion}

Teacher pedagogical competence as used in this study can determine the extent to which inclusive teachers have pedagogical competences which are the basis for the learning process of children with special needs.

Based on the results of research referring to several aspects of teacher pedagogical competence according to Minister of National Education Regulation No. 16 of 2007, it can be concluded that based on teaching experience and educational background, teachers still need to increase efforts to improve pedagogic competence in learning children with special needs in inclusive schools.

Because teacher pedagogical competence is a fundamental thing that must be possessed by education by educators in implementing learning that is in accordance with student characteristics, friendly and open, because the purpose of this inclusive

\section{References}

Arifin, 2017. Upaya Diri Menjadi Guru Profesional, Bandung: Alfabeta.

Departemen Pendidikan Nasional Republik Indonesia. 2003. Undang-Undang Republik Indonesia Nomor 20 Tahun 2003 tentang Sistem Pendidikan Nasional. Jakarta: Biro Hukum dan Organisasi Sekretariat Jendral Departemen Pendidikan Nasional.

Departemen Pendidikan Nasional Republik Indonesia. 2005. Undang-Undang Republik Indonesia Nomor 14 Tahun 2005 tentang Sistem Pendidikan Nasional. Jakarta: Biro Hukum dan Organisasi Sekretariat Jendral Departemen Pendidikan Nasional. 
Departemen Pendidikan Nasional Republik Indonesia. 2005. Peraturan Pemerintah Nomor 19 Tahun 2005 tentang Standar Nasional Pendidikan. Jakarta: Biro Hukum dan Organisasi Sekretariat Jendral Departemen Pendidikan Nasional.

Departemen Pendidikan Nasional Republik Indonesia. 2007. Peraturan Menteri Pendidikan Nasional Nomor 16 tahun 2007 tentang Standar Kompetensi Guru. Jakarta: Biro Hukum dan Organisasi Sekretariat Jendral Departemen Pendidikan Nasional.

Departemen Pendidikan Nasional Republik Indonesia. 2008. Peraturan Pemerintah Nomor 74 Tahun 2008 tentang Standar Kompetensi Guru. Jakarta: Biro Hukum dan Organisasi Sekretariat Jendral Departemen Pendidikan Nasional.

Fitriana, Rona. 2012. Proses Pembelajaran Setting Inklusi di Sekolah Dasar, Jurnal Ilmiah Pendidikan Khusus Vol 1 No. 1

Yasin, Ahmad Fatah. 2011. Pengembangan Kompetensi Pedagogik Guru Pendidikan Agama Islam di Madrasah (Studi Kasus di MIN Malang 1) Jurnal eL-Qudwah Vol. 1 No.5

Puteri, Rizki Utami dan Prasetyo, Arif Partono. 2017. Pengaruh Kompetensi Pedagogik Guru Terhadap Prestasi Belajar Matematikan Siswa (Studi Kasus pada Siswa Kelas XI IPA Negeri 1 Dayeuhkolot). e-Prosiding of Management: Vol. 4, No.3

Musfah, Jejen. 2011. Peningkatan Kompetensi Guru: Melalui Pelatihan dan Sumber Belajar Teori dan Praktik. Kencana Prenada Media Group: Jakarta. 